\title{
DOES CORPORATE SOCIAL RESPONSIBILITY ADD VALUE TO THE INDIAN BANKING SECTOR?
}

\author{
Nitika Gaba \\ Research Scholar \\ DOMS, IIT Madras, India \\ E-mail: nitikagaba1@gmail.com \\ id https://orcid.org/0000-0003-2110-5226 \\ R. Madhumathi \\ Professor \\ DOMS, IIT Madras, India \\ E-mail: rmm@iitm.ac.in \\ https://orcid.org/0000-0002-3601-9964
}

Received: December 09, 2021 Accepted: January 31, 2022 Online Published: February 13, 2022

DOI: $10.46281 /$ ijfb.v9i1.1612

URL: https://doi.org/10.46281/ijfb.v9i1.1612

\begin{abstract}
Corporate social responsibility (CSR) is assumed to have an indirect impact on the performance of the banking sector due to the sector's core non-manufacturing and complex functionalities. This paper examines the value creation for a bank through CSR initiatives considering their earnings persistence and risk exposure in India. The authors measure CSR disclosure through content analysis. CSR scores for 14 items are identified from the annual reports, National CSR Portal, Ministry of Corporate Affairs (MCA, 2021) and websites of 20 Indian banks. Applying OLS and panel regression models, the role of CSR in creating value for the banking sector is established. The study found that CSR commitment has a positive impact on the market value of the banks, along with an adequate liquidity position and business risk. CSR commitment and earnings persistence contribute to the bank's expected operating performance, highlighting its sustainability through CSR investments. Participation of banks for education, healthcare, skill development, and environmental sustainability is associated with higher returns from their lending activities to customers creating social value addition. Specific CSR activities encourage bank customers to repay banks with the implication of business risk reduction for banks.
\end{abstract}

Keywords: Business Risk, Corporate Social Responsibility, Market Value, Social Value, Sustainable Value.

JEL Classification Code: M14, G21.

\section{INTRODUCTION}

In the past few decades in India, banks are focusing more on meeting environmental, social, governance, and economic goals. Financial scandals of 2008 indicate the lack of responsibility by them that could only be restored by strengthening the trust with all stakeholders (Thome, 2020). The banking system in every economy plays a vital role that impact society and also contribute to economic development (Levine, 2005; Scholtens, 2008). Unlike other firms, banks do not produce physical products that 
directly affect society. However, they are obliged to CSR, both directly and indirectly (Thompson \& Cowton, 2004). Investment in CSR activities keeps the banks safe from indulging in unethical events due to their complex nature. They have been playing a crucial role in an economy as an agent of the financial inclusion process (Carbo-Valverde et al., 2015). The trust with the public after their collapse in the 2008 crisis can be restored by focussing on CSR commitment. After the Montreal carbon pledge signed by various banks worldwide in 2014 to measure and disclose the harmful gas emissions data of their financial assets on an annual basis; they have become more aware of the implications for CSR activities (Caby et al., 2020). Banks, in contrast to other sectors, are subject to stricter scrutiny in their reporting practices to stakeholders such as the government, media and lenders. This demands more attention in creating benefits for the society as they receive government bailouts or guarantees during tough times (Iannotta et al., 2013).

Literature on CSR and performance relationship has gained momentum after being mandated by Section 135 of the Companies Act of 2013 in India. Although, it is not mandatory for banks, but they have realized that achieving social goals is as crucial as providing shareholder value. The prior literature has used both market-based measures and accounting-based measures to evaluate the impact of CSR on financial performance (Van Beurden \& Goessling, 2008). The impact of CSR on market and accounting performance convey to various stakeholders their worth and the internal utilization of resources of the banks.

For enhancing social value, firms usually advertise CSR activities along with their products and services that raise awareness among existing and potential customers. Most often, customers besides transacting in new products and services, have better corporate relationships through CSR that leads to positive marketing performance and higher market share (Servaes \& Tamayo, 2013). However, Mittal et al. (2008) reported that Indian firms with a code of ethics generated little more value than those without codes on CSR.

CSR commitment also impacts the operating performance of a bank by evaluating the cost and benefits of CSR activities in the context of productivity and cost efficiency, which are dependent on firm's characteristics such as location, laws, etc. (Paul \& Siegel, 2006). These research arguments on the convergence of CSR activities with the market, accounting and operating performance highlight the need for stakeholder engagement that adds to value creation. Delivering value involves making the right decisions by profitability planning which includes CSR allocation. These are enabled by good marketing, accounting and operating performance management that provides necessary resources and processes, revenues and costs and risks and value objectives.

\section{CSR and Market Value}

Market value impact in banking sector can be added through several mechanisms like costs, operational efficiency, sales, litigation and financial risk by providing disclosure in annual reports to meet the information demand of various stakeholders. Cheng et al. (2013) highlighted the role of capital markets in creating long-term value creation and increased market performance by adopting CSR strategies. CSR not only affects market value directly but also has some indirect effects through value relevance of earnings and book value of equity. CSR disclosure provides information that allow investors to make a better assessment of risks, which is reflected in higher market valuation of shares of the firms.

\section{CSR and Sustainable Value}

We live in a world where there are limited resources and growing pressure by humans on these constrained resources. Earlier, firms have only concentrated on economic value but now they are becoming fully aware of the potential value outcomes. The changing business environment and resource limitations have raised the need for sustainable value creation. CSR positively impacts the operating performance of a bank by decreasing the operating costs to its net interest income by channel optimization, process costs, benchmarking, attracting good talent and staff productivity, vendor relationships, technology, automated workflow process, thereby increasing the bank's sustainability. Value is created by saving resources from the costly operations and redirecting them to the areas where 
there are new opportunities for the bank. When we reduce any uncaptured value, sustainable value is created for example, overcapacity of labour, under-utilized resources, etc.

High persistent earnings imply a sustainable earnings generation process that investors highly value. Earnings persistence is determined by good strategic positioning and operating decisions with the help of right commitment of money towards CSR activities. The firms have to continue to generate sustainable value despite disruptive forces, turbulent regulatory conditions and other pressures. Top management strategically position their firms by connecting performance with a purpose for long-term sustainable value creation. Firms with more accruals can have the ability to manipulate their earnings in the future, and such strategic positions imply higher chances of non-sustainable returns.

\section{CSR and Social Value}

Socially responsible actions are associated with capital adequacy, high liquidity and low non-performing assets which increases the bank's operating performance by lowering moral hazard between bank shareholders and debtholders (Lotto, 2019). Banks create social acceptance by investing in diversified CSR activities like education, training, skill development, healthcare, technology, etc. The social impact of banks prompts bank customers to return the borrowed assets, which lowers the non-performing loans and enhances the reputation in the long run. Social value creates a positive change by social intervention in the subjective well-being of disadvantaged individuals and communities (Kroeger \& Weber, 2014).

CSR activities of banks will encourage the industry to participate more towards the Environmental, Social and Governance (ESG) goals of India. However, there is a need to justify that such CSR investments will be sustainable by the industry in the long term. The recognition of CSR activities by bank customers is crucial since banks hold a large part of their assets in lending activities. Hence, there is a need to identify the role of CSR investment by banks towards market value, its ability to sustain the CSR investment in the long term and the impact on bank customers to identify the social value created by the industry. This paper focuses on addressing the impact of CSR commitment on a bank's market value, sustainable value and social value.

\section{LITERATURE REVIEW AND HYPOTHESES DEVELOPMENT}

Existing literature on CSR elaborates the impact on firm performance, but very few studies discuss CSR and value creation (Ding et al., 2016, Alotaibi \& Hussainey, 2016). Firm performance is elaborated as CSR impact on market value, sustaining operating performance and asset value generation through CSR activities. Further, literature discussion on bank specific factors such as business risk, governance and reporting practices and bank liquidity lead to the research design and development of a testable hypothesis.

\section{CSR and Market Value}

Researchers in accounting and finance apply surrogates like Tobin's q, share price, cost of capital and market value addition to measure market value as a theoretical construct of firm performance. Market valuation represents the investor's expectation of the firm to generate returns which are diverted as investment in CSR. Additionally, CSR strategies emphasize firm's own idiosyncratic resources and capabilities rather than just replicating competitor's choices which lowers business risk and improves earning quality. Stakeholder theory also reflects the importance of the firm's interests of various people (stakeholders) who are affected by it directly or indirectly. To succeed in the long term, it has to meet their expectations, which is met by investing in CSR activities that increase market value (Nekhili et al., 2017).

Dhaliwal et al. (2011) state that disclosure of CSR is useful for shareholders through several mechanisms like revenue, costs, operating efficiency, litigation risk and financing. Further, Deniz and Suarez (2005) applied cost-benefit analysis and found that there is an increase in market value of the firm with an increase in CSR expenditure. There is an inverse relationship between higher levels of CSR and lower cost of equity capital (Sherfman \& Fernando, 2008; Orlitzky \& Benjamin; 2001). CSR performance impacts firm value by lowering market risk expectation. Alsaid (2016) and Ferrell et al. (2016) also supported their argument that consistent CSR activities help in increasing earnings and firm 
value. Other factors like adherence to tax obligations enhance CSR evaluations, thereby adding market value. Zeng (2016) using their sample of Canadian firms found that paying more taxes contributes to higher overall CSR ranking and thus enhances firm's market value. In contrast, Palazzo et al. (2020) inferred that bank show less prominence to strategic CSR and value creation than other firms.

Very few studies concentrated on the relationship between CSR and market value in the banking sector. Market performance (value) is measured as an efficiency indicator since the value of the financial assets is the primary component of their total asset structure (Jiao, 2010, Fatemi et al., 2015). Belasri et al. (2020) measure bank efficiency as a microeconomic variable of productivity that evaluates the production process considering the volume of both inputs and outputs. Fund utilization efficiency is reflected by the ability of the bank to generate market value based on its assets. For our study, the following hypothesis is framed:

\section{$\mathrm{H}_{1}$ : CSR commitment, increases the market value of banks.}

The hypothesis tests the market value potential of CSR investment by banks.

\section{CSR and Operating Performance (Value Sustenance)}

CSR commitment today impacts the future operating performance of a bank. CSR contribute to the operating performance by improving resource utilization process. The implementation of CSR practices helps in increasing productivity and minimize wastage (He et al., 2020). Activities like board governance get stakeholder's support, improve management abilities which help in effective resource deployment. Investors also believe that socially and environmentally responsible firms use their resources efficiently. Second hypothesis framed as:

$\mathrm{H}_{2}$ : CSR commitment has a positive impact on bank's future operating performance.

The testing of this hypothesis addresses the sustainability of CSR activities of banks for future performance.

\section{CSR and Social Value}

CSR activities are usually divided into internal and external categories. Internal CSR are the internal policies and practices of the firm which are related to employees like human rights, employee-wellbeing, work-life balance, diversity, etc. External CSR activities can be defined as volunteerism, philanthropy, etc. (environmental and social practices) mainly cater to external stakeholders (Brammer et al., 2007).

Investors pay attention to the social performance of the firm as pointed out by various scholars in the past. They reported that it has relationship with return on assets (ROA). For instance, McGuire et al. (1988), Luo and Bhattacharya (2019) and Lin et al. (2009) demonstrated that firms which have low social responsibility also experience lower return on assets (ROA) than firms which have high social responsibility. All CSR activities didn't increase the value of the bank, only core activities which were a part of bank's operating mission increased their value (Bolton, 2013). ROA of a bank indicates the efficiency of a bank management through its ability to convert bank assets (customer loans) into net earnings. As banks are dominated by customer centric loans, ROA captures the positive impact of social value. ROA reflects systematic market trends that is not influenced by the differential degree of leverage present in a firm (Mishra \& Suar, 2010). Researchers reported positive relationship between CSR and ROA (Bodhanwala \& Bodhanwala, 2018; Garcia-Castro et al., 2010, Giuli \& Kostovetsky, 2014). In contrast, Hafez (2015) reported negative and no relationship between CSR and ROA. The third hypothesis is framed as:

$\mathrm{H}_{3}$ : Bank's CSR scores increases its return on assets. 
This hypothesis tests how social activities of banks enables bank customers to have a positive impact, thus increasing the return on assets for the banks

\section{Earnings Quality and Persistence}

Over the years, earnings manipulation has been observed in banks particularly during financial crisis in 2008. During the crisis, shareholder's perception of manipulated earnings of a bank had led to immediate stock market losses. This type of financial meltdown has erode confidence in the integrity of the top management; that may have serious consequences for the society as a whole. This problem can be mitigated by having a certain set of structures, rules and systems internally and externally to align the interests of the managers of a bank with various stakeholders. This system can be embedded in a bank through good CSR performance which will improve market confidence in the long run. In addition, transparency in CSR reporting reduces the chances of earnings manipulation that leads to bank stability.

Earnings persistence suggests the stability of our earnings and how well the present earnings can help banks to predict future earnings. If earnings are persistent, then there are less chances of earning manipulation i.e., management. Beneish (2001) states that earnings management (EM) occurs when managers seek to either deceive stakeholder perception or provide private information on the firm's future performance. Kim et al. (2012) showed that CSR firms are less likely to engage in aggressive EM through discretionary accruals or real activities manipulation. Grougiou et al. (2014) examined US's banks and established that low accounting earnings and high investment in intangibles are associated with intensive investment in CSR activities.

Earnings persistence reflects the quality of the profit of a firm and shows that the firm can retain earnings over time instead of an event of a particular activity. It imply sustainable profit stream and thereby are good evidence for earnings quality (García-Sánchez \& García-Meca, 2017). Accruals play a matching role by reflecting transitionary special items adjustments that reduce earnings persistence (Dechow \& Ge, 2003). Accrual adjustments in firms that have positive accruals improves earnings persistence. On the other hand, firms which have negative accruals in their balance sheets, made efforts to write down assets to their fair value. However, earnings persistence may represent earnings smoothness through loan loss provisions implying lower reporting quality.

Research also reported that CSR has more effect in countries where there is more investor protection and regulation in banks (García-Sánchez \& García-Meca, 2017; Chih et al., 2008, Kim et al., 2012, Prior et al., 2008, Hong \& Anderson, 2011). Kanagretnam et al. (2014) used a sample of banks from 35 countries indicating stronger legal and political institutions are associated with higher levels of earnings persistence cash flow predictability and greater ability of current periods loan loss provisions to predict next period's loan charge offs.

Literature reveals that managers enhance a firm's financial position by building a profitable business with all the stakeholders (Greening \& Turban, 2000; Mishra \& Suar, 2010). Being committed to CSR implies good governance practices and earnings quality thereby leading to enhanced operating performance of the firm and thereby creating sustainable value. These studies motivated us to frame the following hypothesis:

$\mathrm{H}_{4}$ : CSR commitment and earnings quality have a positive impact on performance.

\section{Bank Specific Characteristics \\ Bank Liquidity and Market Value}

There are many theoretical reasons which support the fact that market liquidity enhances market value positively. Liquidity stimulates the entry of informed investors who makes prices more informative to other investors. Khanna and Sonti (2004) and Nguyen (2016) reported that higher prices signal good prospects to managers which affects their investment decisions and firm value. They further stated that 'the effect of liquidity is proportional to the sensitivity of firm's operations and the information content of stock prices. The effect of trades on managerial behaviour is factored in the trading strategies by informed traders which helps in making the price more informative. Liquidity improves the operating performance and market value. Therefore, we formed the next hypothesis as: 
$\mathrm{H}_{5}$ : Bank liquidity has a positive impact on its market value.

\section{Banks and Risk Management}

Reputation theory assumes a restrictive lending process as banks with low risk are characterized by rigorous credit assessment and with less risky assets than their competitors (Nandy \& Lodh, 2013). While risk mitigation theory states that CSR creates a moral capital which increases value if it aids stakeholders in attributing the negative event to managerial unskilfulness rather than enmity and temper their reactions accordingly (Godfrey et al., 2005). The stakeholders will impose less strict rules on those banks which has high CSR due to higher moral capital. The Merton (1987) model is also consistent with this argument that risk management and socially responsible activities are valued. Management knows the value of a bank's reputation as banks with good reputation attracts more value that allows them to charge a premium. Since, the market believes that such banks will deliver sustained earnings and future growth due to having high price to earnings ratio and lower cost of capital. Kayode et al. (2015) reported that increased credit risk disrepute and lowers bank profit margins. Wood and Mc-Conney (2018) examined the effect of risk factors on the financial performance of the selected banks and reported that credit risk has a negative effect on their financial performance. Most of the existing literatures reported a negative relationship between CSR and risk. Firms who want to stay in the market must change dynamically their exposure to risk. Banks with low risk usually focus on saving costs as investment in banking requires fixed costs and compliance costs. Banks are also interlinked with the capital markets as they have to manage their exposure in off-balance sheet products like forex, forward and swaps contracts. High exposure can be a worry as there can be huge market fluctuations that's why banks should continuously measure their exposures to evaluate the impact of market changes on counterparty positions. Therefore, the last hypothesis is framed as:

\section{$\mathrm{H}_{6}$ : Business risk has a negative impact on market value.}

\section{CONCEPTUAL FRAMEWORK}

The conceptual framework links dependent variables: market value, social value and sustenance value with the independent variables (Figure 1). CSR commitment, CSR scores, earnings persistence, liquidity, operating performance and business risk. Literature on CSR disclosure has applied various classes of information categories and measurement units. To assess the extent of CSR disclosures in annual reports, a checklist containing 14 items is constructed (Appendix A). Krippendorff (1980) defines content analysis as 'a research technique for making replicable and valid inferences from data according to their context'. Researchers apply a dichotomous coding procedure where a bank is scored as '1' if an activity included in the checklist is reported and ' 0 ' if it is not reported (Rashid \& Lodh, 2008). The CSR scores are derived by computing the ratio of number of items disclosed to the maximum expected items of disclosure by each bank (Mohd Ghazali, 2007). The maximum score is 14 implying that the banks in the sample have deployed their funds in 14 socially beneficial CSR activities (Appendix B). The approach to scoring is additive and equally weighted (Haniffa \& Cooke, 2002). A larger score suggests diversified CSR deployment by a bank.

$\operatorname{CSR~Score~}_{j}=\left(\sum_{t=1}^{n} X_{i j}\right) / N_{j}$

CSR Score $=$ Corporate social disclosure scores for the jth bank

$\mathrm{N}_{\mathrm{j}}=$ number of activities expected for the $\mathrm{j}^{\text {th }}$ bank, where $N \leq 14$

$\mathrm{X}_{\mathrm{ij}}=1$, if ith CSR activity is disclosed for firm $\mathrm{j}$ year $\mathrm{i}$, otherwise 0 ;

$0 \leq$ CSR Score $\leq 1$.

\section{Empirical Models}

Multivariate regression analysis is used to test the formulated hypotheses.

(Model 1): $\mathrm{PTB}=\frac{\mathrm{CSR}}{\mathrm{TA}}+\frac{\mathrm{EBIT}}{\mathrm{TA}}+\mathrm{NPA}+\mathrm{CDR}+\mathrm{EQ}+\mathrm{e}$ 
(Model 2): $\frac{\mathrm{EBIT}}{\mathrm{TA}}(\mathrm{t}+1)=\frac{\mathrm{CSR}}{\mathrm{TA}}+\mathrm{EQ}+\mathrm{e}$

(Model 3): $\mathrm{ROA}=\mathrm{CSR}$ scores $+\mathrm{EQ}+e$

Where: PTB: $\log -\ldots . . . \mathrm{e}$

The hypotheses are modelled to capture the value creation for a bank through its CSR.

Model 1 examines the market value creation process of CSR commitment along with operating performance, business risk, earnings persistence and bank liquidity.

Model 2 examines the bank's ability to sustain its future operating profits with CSR investment and earnings persistence.

Model 3 captures the social value to a bank from CSR activities.

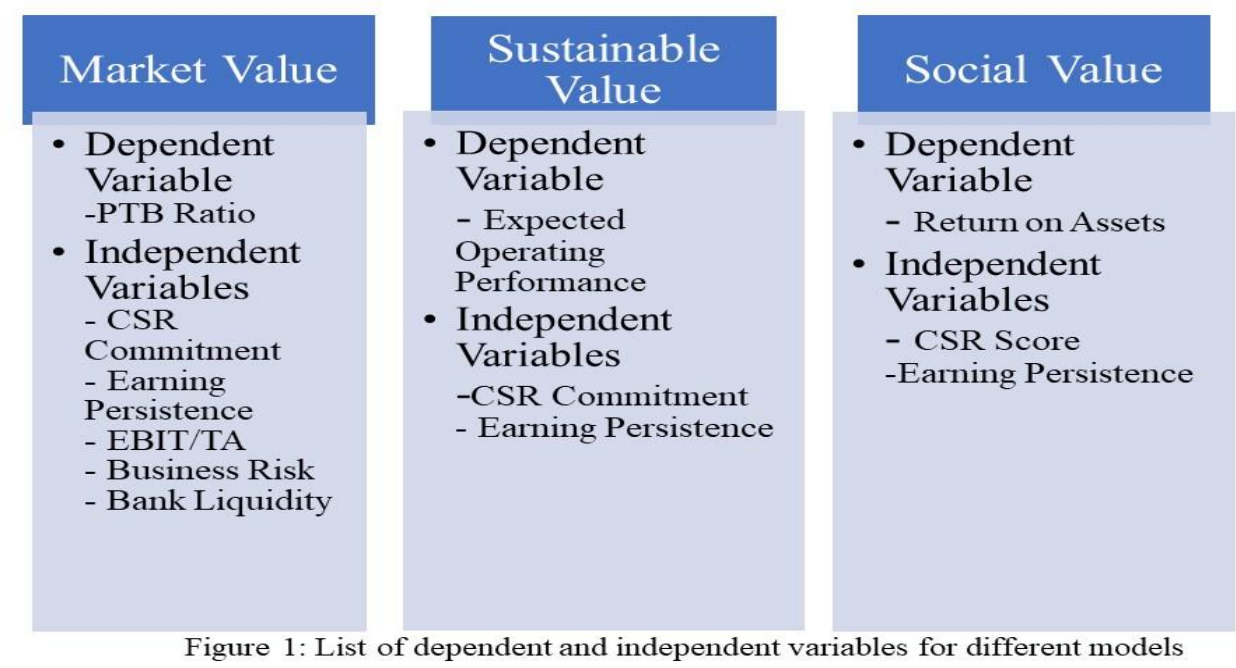

\section{Source of Data, Study Period and Sample}

\section{RESEARCH METHODOLOGY}

The study used secondary data for empirical analysis. Of the total 40 banks including public banks (18) and private banks (22) as reported by RBI's statistical tables of liabilities and assets of banks (https://dbie.rbi.org.in/DBIE/dbie.rbi?site=publications\#!4), we have selected the sample of 20 banks (10 public and 10 private) who published CSR data from 2014-15 to 2018-19 (Appendix B). Data of the selected banks was collected from various sources i.e., annual reports, CSR reports, and National CSR Portal. We collected information from various sources to eliminate any deficiency from only one source (Oxibar, 2005). All these 20 banks listed in BSE together represent $52.63 \%$ market share of the Indian banking sector and exhibit high visibility to stakeholders.

In our empirical research analysis, OLS and random effect regression models are used to test the hypotheses. A bank's CSR score, CSR commitment, earnings persistence, financial performance, business risk and bank liquidity are (Table 1) considered for model testing with STATA software tool.

\section{Measurement of Variables}

Table1. Measurement of Variables

\begin{tabular}{|l|l|}
\hline \multicolumn{2}{|l|}{ Dependent Variables } \\
\hline Variables & Measurement \\
\hline Market Performance (Market Value) & $\begin{array}{l}\text { Log of Price to Book Value } \\
\text { It tells us about the expectation of the investors of how much } \\
\text { shareholder value the bank's management will be able to } \\
\text { create from a given stock of assets and liabilities (BIS, 2021) }\end{array}$ \\
\hline
\end{tabular}




\begin{tabular}{|l|l|}
\hline $\begin{array}{l}\text { Expected operating performance } \\
\text { Sustainable Value) }\end{array}$ & EBIT/TA(t+1) \\
\hline Financial Performance (Social Value) & $\begin{array}{l}\text { Return on Assets } \\
\text { The dominant asset category of a bank in India is the } \\
\text { customer centric loan portfolio. This ratio thus indicates the } \\
\text { ability of banks to generate returns from its (customers) } \\
\text { implying social value }\end{array}$ \\
\hline CSR Commitment & Independent variables \\
\hline Diversified CSR Scores & CSR Expenses \\
\hline Bank Liquidity & Control Variables \\
\hline Operating Performance & Credit Deposit Ratio \\
\hline Earnings Persistence & EBIT Scaled by Total Assets \\
\hline Business Risk & $\begin{array}{l}\text { Coefficient in a Regression of Future Earnings on Current } \\
\text { Earnings Kanagaretnam et al. (2014). }\end{array}$ \\
\hline & NPA to Net Advances (\%) (Caiazza et al., 2018). \\
\hline
\end{tabular}

EMPIRICAL RESULTS AND DISCUSSION

OLS and panel regression models after checking for heteroskedasticity and Hausman test are applied to test the hypothesis. Banks have an average of six CSR activities (0.45 CSR score) among the 14 activities in the checklist during 2014 to 2019 (Appendix A). Maximum CSR score is 0.93 in year 2017 indicating participation in almost all 14 activities. The average CSR expenditure spent by the banks scaled by total assets is $7.46 \%$ per million crore asset value (Table 2).

Table 2. Descriptive Statistics

\begin{tabular}{|l|l|l|l|l|l|}
\hline Variable & Observations & Mean & SD & Min & Max \\
\hline CSR Obligation (\%) & 100 & 1.29 & 2.38 & 0.09 & 20.89 \\
\hline CSR Score & 100 & 0.45 & 0.16 & 3.00 & 0.93 \\
\hline $\begin{array}{l}\text { CSR Commitment (\% per } \\
\text { million asset value) }\end{array}$ & 100 & 7.64 & 8.04 & 0.00 & 0.03 \\
\hline Market Value (times) & 100 & 1.63 & 1.56 & 0.32 & 7.17 \\
\hline $\begin{array}{l}\text { Social Value (\%) } \\
\text { (ROA) }\end{array}$ & 100 & -0.64 & 1.13 & -4.68 & 2.46 \\
\hline $\begin{array}{l}\text { Sustenance Value (\%) } \\
\text { (Expected Operating } \\
\text { Performance) }\end{array}$ & 100 & 5.17 & 2.90 & -3.84 & 14.83 \\
\hline $\begin{array}{l}\text { Earnings Persistence } \\
\text { (Coefficient) }\end{array}$ & 100 & -0.24 & 3.55 & -14.87 & 12.51 \\
\hline Business risk (\%) & 100 & 3.94 & 3.36 & 0.12 & 16.69 \\
\hline $\begin{array}{l}\text { Liquidity (\%) } \\
\text { (Credit deposit ratio) }\end{array}$ & 100 & 78.34 & 9.89 & 54.45 & 105.08 \\
\hline
\end{tabular}

The CSR obligation is way below the $2 \%$ regulatory requirement for a few private banks. Average CSR obligation is $1.29 \%$ and the maximum of $20.89 \%$ for a public bank in 2018. The average PTB value is 1.63 times, with the maximum of 7.17 in 2015. The average ROA (Social value) is negative ($0.64 \%$ ). However, it varies between the minimum value of $-4.68 \%$ (2019) and the maximum of 2.46 
$\%$ (public bank in 2018). Expected operating performance (Sustenance value) on an average is $5.17 \%$ and varied between a minimum values of $-3.84 \%$ in 2019 and a maximum value of $14.83 \%$ in 2019 indicating moderate core profit for the banks. Business risk measured through the NPA to net advances ranged from a minimum of $0.12 \%$ recorded in 2015 and a maximum of $16.69 \%$ recorded in 2018 .

Earnings persistence of banks in our sample has a negative coefficient of -0.24 . Negative coefficients imply the low reporting quality for banks. This is a coefficient between prior earnings and current earnings. A negative coefficient implies that if prior earnings increases, then current earnings decreases. The earning persistence was fluctuating for all the selected banks during the period under study.

The average credit deposit ratio for the selected banks is $78.34 \%$. This level peaked at $105.08 \%$ in 2016 indicating a tight liquidity position for a bank and reached $54.45 \%$ for another bank in 2019 implying relaxed liquidity. The liquidity was more for private banks i.e., $81.1 \%$ in comparison to public banks $(72.53 \%)$.

Table 3 show that the correlation between market value with CSR commitment and liquidity is significant and positive. There is a negative and significant relationship between business risk and CSR commitment, market value and liquidity. There is also a negative relationship between expected operating performance and business risk. These correlations are below the 0.80 multicollinearity threat threshold.

Table 3. Correlation Matrix

\begin{tabular}{|c|c|c|c|c|c|c|c|c|}
\hline Variables & \multicolumn{8}{|c|}{ Correlation among Variables } \\
\hline & (1) & (2) & (3) & (4) & $(5)$ & (6) & (7) & (8) \\
\hline (1) CSR score & 1.00 & & & & & & & \\
\hline $\begin{array}{l}\text { (2) CSR } \\
\text { commitment }\end{array}$ & $0.30 * *$ & 1.00 & & & & & & \\
\hline $\begin{array}{l}\text { (3) Market } \\
\text { Value }\end{array}$ & 0.14 & $0.55^{* *}$ & 1.00 & & & & & \\
\hline $\begin{array}{l}\text { (4) Social } \\
\text { Value }\end{array}$ & $0.29 * *$ & 0.15 & 0.12 & 1.00 & & & & 0.13 \\
\hline $\begin{array}{l}\text { (5) Expected } \\
\text { operating } \\
\text { performance } \\
\text { (5) Earnings } \\
\text { persistence }\end{array}$ & -0.01 & 0.14 & $0.17 *$ & $0.22 * *$ & 1.00 & & & $0.27 * *$ \\
\hline $\begin{array}{l}\text { (6) Expected } \\
\text { operating } \\
\text { performance }\end{array}$ & 0.14 & $0.29 * *$ & $0.21 * *$ & 0.12 & $0.24 * *$ & 1.00 & $-0.58 * *$ & $0.31 * *$ \\
\hline $\begin{array}{l}\text { (7) Business } \\
\text { risk }\end{array}$ & $0.23 * *$ & - & $\begin{array}{c}- \\
0.52 * *\end{array}$ & -0.12 & -0.14 & & 1.00 & \\
\hline (8) Liquidity & 0.15 & $0.56^{* *}$ & $0.59 * *$ & & & & & 1.00 \\
\hline
\end{tabular}

Notes: $* * \mathrm{p}<0.05 ; * \mathrm{p}<0.1$

Table 4 indicates that private sector banks in the sample have high CSR scores and CSR commitment than public sector banks and the difference is strongly significant at $5 \%$ level. 
Table 4. Comparison across Private and Public Banks

\begin{tabular}{|c|c|c|c|}
\hline & \multicolumn{3}{|c|}{ T-test } \\
\hline Variable & \multicolumn{2}{|c|}{ Mean } & P -Value \\
\hline CSR Commitment & Private Banks & Public Banks & 0.006 \\
\hline CSR Score & 55.36 & 19.03 & 0.000 \\
\hline
\end{tabular}

Table 5. Regression Models

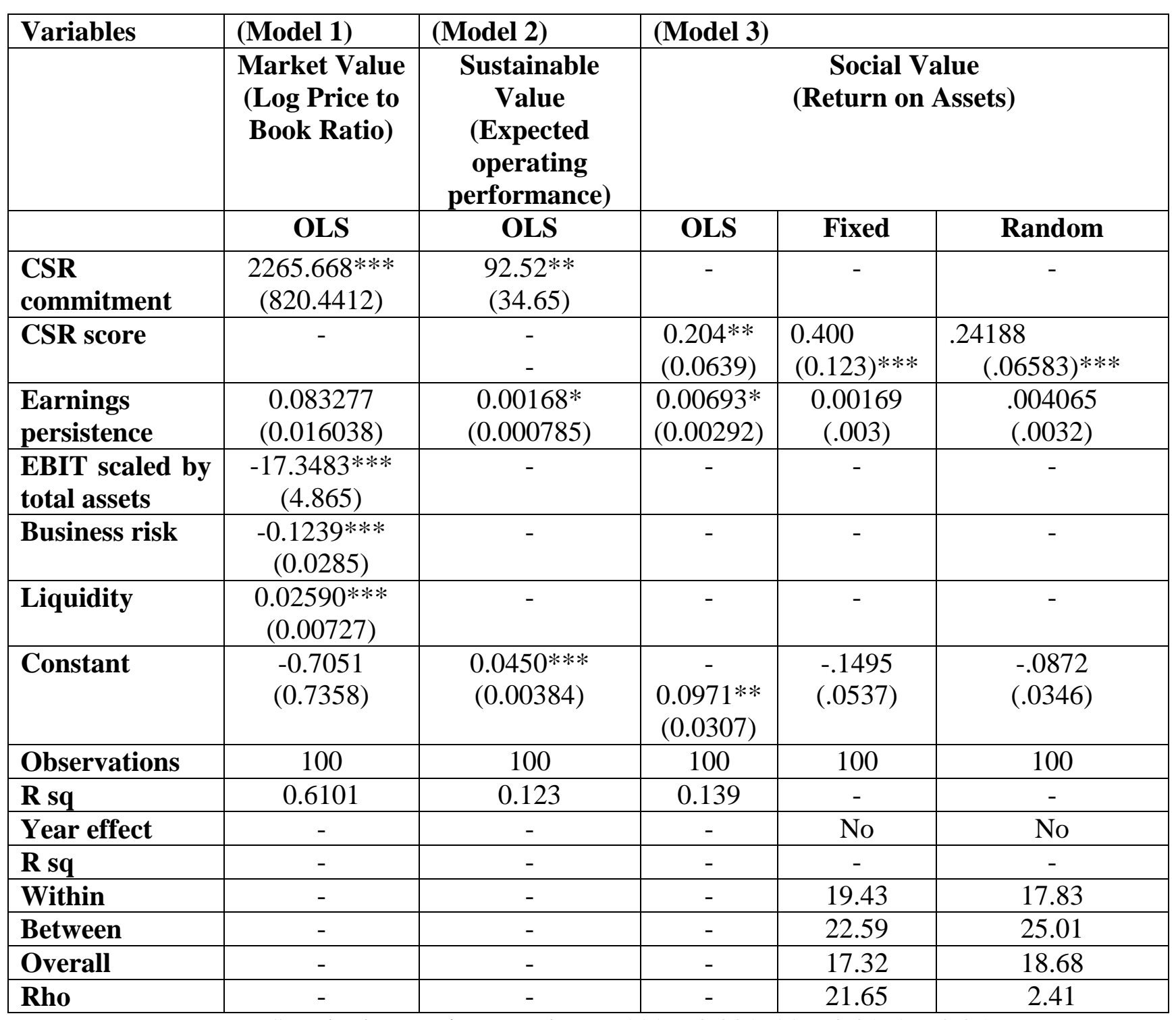

Notes: Standard errors in parentheses; $* * * p<0.001, * * p<0.01, * p<0.05$

Source: The author's

The regression analysis results of the three models (Table 5), are indicated by the beta coefficient and the standard errors in parentheses of each variable under investigation.

\section{Market Value Creation by CSR}

Breusch-Pagan test (BP test) for Model 1 was non-significant implying that OLS regression results are consistent $(\mathrm{Chi}$ square $=0.02)$. The model is significant with an explanatory power of $61.01 \%$. The 
positive effect of CSR on the bank's market value is confirmed by the beta coefficient (2265.66); an increase of one unit of the CSR commitment leads to an increase in the log of price to book ratio thus improving the market value of the bank many folds (Belasri et al., 2020). The high coefficient indicates a strong relationship between the CSR commitment and market multiplier in relation to its book value. For UCO Bank, which is having very high CSR commitment, if we increase commitment towards CSR by $1 \%$, then market price will increase from INR 19.2 to INR 42.75 in 2019 while for a bank which has low commitment towards CSR if we increase CSR commitment by $1 \%$, then CSR commitment increases from INR 1839.45 to INR 1839.59 in 2019 (HDFC Bank). Besides CSR, the value creation for banks is also significantly supported by the liquidity position of the banks. Value creation is also supported from reduced business risk and operating profit. The results are in line with Dhaliwal et al. (2011) and Alsaid (2016). The negative coefficient of the operating profit indicates the negative value additive component of core financial functions such as the interest rate spreads for a bank to its market value. In India, the spread from operations does not significantly differentiate competitive operating performance. Rather fund and fee-based services are considered by the shareholders as value creation activities of a bank. The negative coefficient of business risk implies the value addition to the bank through reduced business risk exposure.

Banks which commit more to CSR are rewarded better than banks which have low commitment towards CSR which leads to the acceptance of hypothesis 1 . If the operating profit is increased by $1 \%$ for a bank, then the market value is negatively affected (accept hypothesis 4 ). For an increase in liquidity position of a bank by $1 \%$, the market value will increase by $2.623 \%$ accepting hypothesis 5 and if there is an increase in business risk by $1 \%$, then market value of the banks decrease by $11.65 \%$ accepting hypothesis 6.

\section{Sustenance of Value Creation by CSR}

In Model 2, the Breusch-Pagan test (BP test) for expected operating performance is not significant as the chi-squared was 2.86 with p-value $9 \%$. The result implies that panel data is rejected. As a result, OLS regression is good for the model with expected operating performance. Model 2 results indicates that each unit increase of CSR commitment lead to a rise in expected operating performance by 92.52 , as confirmed by the positive and significant coefficient $(\mathrm{p}<0.01)$. Earnings persistence is also significant and positively related to expected performance in line with Greening and Turban (2000) and Mishra and Suar (2010). If a bank has larger commitment to CSR, it has a positive impact on its operating performance and earnings persistence of the firm. The activities in which a firm commits for CSR are value adding activities. Thus, these value adding activities through their business models transform various inputs to produce output like loans, deposits, etc. They act as an operating profit sustenance strategy for the firm. Sustainable value creation is a long-term process which requires management orientation for persistent and stable earnings with continuous commitment to CSR and improves firm's stability and resilience. Firms which give attention to CSR, balance their interests with multiple stakeholders. Balancing such interests and allocation of resources to all the stakeholders reduces excessive risk taking and excessive risk avoidance which increases their sustainability in the long term. The behaviours of the firm which balance financial and non-financial dimensions to manage risks and opportunities with economic, environmental and social development leads to sustainable value creation. The biggest challenge faced by the banking sector is to take more long-term and integrated approach which is resolved by sustainable value creation. Sustainability requires balancing long-term and shortterm objectives for the firm. Therefore, we accept hypothesis 2 that the sustainability of CSR activities is evident for banks.

\section{Social Value Creation by CSR}

Model 3 is significant with an explanatory power of $13.9 \%$ using the OLS regression. The explanatory variables CSR score and earnings quality are (1\% and $5 \%$ ) significant (Table 5). For a unit increase in CSR score, holding all other factors constant, return on assets (ROA) will increase by $20.4 \%$ at $1 \%$ significance level. The model also establishes a positive significant impact of earnings persistence in line with stakeholder theory (Freeman, 1984 \& Waddock \& Graves, 1997). BP test for the 3rd Model 
with the chi-squared value (443.66) is highly significant at 5\% level. It means the OLS regression is not consistent for this model and possible model which can be applied are fixed or random effects model. The hausman test was applied to determine a good model. The chi square value (2.81) is not significant implying that random effects (REM) regression is consistent for the $3^{\text {rd }}$ model. The results of the specification tests attested that the random effects model is best for understanding the CSR and ROA relationship. The relationship between CSR and financial performance measured through ROA is strong $(\mathrm{p}=0.000)$. The $\mathrm{R}$ square for the REM regression of model is $18.68 \%$. As anticipated, the CSR score is highly significant, which confirms that CSR diversified activities create social value in line with the results of Mitra et al. (2018) and Bodhanwala and Bodhanwala (2018). Disclosure of CSR investment in different diversified areas helps to create a long-term social value for banks. Consumers, government and other stakeholders view banks as a catalyst for value creation. By disclosing CSR efforts in education, healthcare, etc., a bank increases its financial performance. The positive relationship between CSR and financial performance is in line with the stakeholder theory representing shared values leading to collective social intention. We accept our hypothesis 3 that banks CSR scores increases its return of assets.

\section{Robustness Checks}

The structural validity of Model 1 is well established as the explanatory variable significantly influences all the dependant variables formulated in the study. Moreover, the tested hypotheses have literature support and are backed by stakeholder theory. We dropped variables other than CSR from all the models 1 , the results for the dependent variables were unchanged and were significant. We also computed variance inflation factor (VIF) when estimating our regression models to test signs for multi-collinearity between the explanatory variables. As no VIF exceeded ten, we concluded that multi-collinearity is not a major concern in the study.

\section{DISCUSSION}

Banking sector is a very important part of an economy. Its activities affect people since its services are linked to other organisations. This study is a modest attempt to identify the impact of CSR disclosure to create value for the Indian listed banks during the period 2014-15 to 2019-20. The prior studies do not extensively study the banking sector as an individual sector especially in India. The research attempts to reconcile the conflicting understanding of the nexus between CSR, business risk, earnings quality, financial performance and value.

The present study provides evidence that CSR investments have impact on their market value, social value and sustenance value. For banking sector, CSR is a great opportunity to utilize their strengths to benefit the local community.

Banks can enhance their long-term value by carefully scrutinizing the project proposals for financing those projects that do not harm the environment. The results indicate importance of CSR activities and governance factors like earnings persistence in enhancing the value of banks. The relationship between CSR commitment and value of banks has huge policy implications. Investment in diversified CSR activities gives competitive advantage. Commitment to CSR activities in diversified areas along with improved earnings persistence helps in both sustainable and social value creation respectively. The investment in CSR activities is related to the moral and ethical behaviour of banks which improves the satisfaction of the stakeholders. There has been a huge debate on efficiency of banks regarding their investment towards CSR activities to be more responsible towards the need of the stakeholders. The present study establishes the fact that investment in diversified CSR activities and continuous CSR commitment create tangible values for the banks. It enhances the long-term value for them as the mutual relationship between banks and the society. Demonstrating social value also means differentiating from the competition. Various stakeholder's expectations are met by investing in diversified activities. By spending on different areas of CSR, local communities are also benefitted which enhances the social value of the bank. During recent years, the social value has garnered attention as all the stakeholders like government, media, etc. are interested in knowing whether the investments are reflecting genuine value to the society. 
The study establishes three value creation functions of CSR for banks in India. First positive CSR commitment, liquidity and earnings quality leads to market value creation, while business risk has a negative impact. If the markets are efficient, a positive CSR engagement will be embedded in the stock prices. Investors perceive how CSR is articulated and its quality, consistency, effectiveness and take these factors into account for decision making which increases the market value. Second, there is a positive relationship between CSR, earnings quality and expected operating performance confirming the sustenance of CSR value creation for banks. Third, diversified CSR activities enhances the social value of the banks through its asset returns.

\section{CONCLUSION}

The present study results are subject to several limitations, which could lead to further research both empirical and theoretical. First, the current study is limited to examining banking sector in India, while this study can be extended further with an international sample of banks. Second, the generalizability of the results in this paper is subject to data collected from public disclosure of banks. It can be pointed out that several banks contribute to CSR that may not be reported and thus hidden value creation by such CSR activities needs to be brought out in the future. Different results may be obtained when different firms in other sectors are used. The question of CSR contribution by specific industries also needs to be dealt with in the future. We can compare the firms that are legally required to carry out CSR with those firms that willingly commit to CSR. Further research may evaluate if CSR hedge interest rate risk, market risk (beta) and tax risk (effective tax rate). In the present study, we have only used a few proxies for measuring value of the firm. The future studies can explore more indicators along with panel dataset among various countries. To conclude: our results will be useful to policy makers, academicians, top management while making sustainable strategies.

Conceptualization: Nitika Gaba, R.Madhumathi

Data Curation: Nitika Gaba, R.Madhumathi

Formal Analysis: Nitika Gaba, R.Madhumathi

Funding Acquisition: Nitika Gaba, R.Madhumathi

Investigation: Nitika Gaba, R.Madhumathi

Methodology: Nitika Gaba, R.Madhumathi

Project Administration: Nitika Gaba

Resources: Nitika Gaba, R.Madhumathi

Software: Nitika Gaba, R.Madhumathi

Supervision: Nitika Gaba, R.Madhumathi

Validation: Nitika Gaba, R.Madhumathi

Visualization: Nitika Gaba, R.Madhumathi

Writing - Original Draft: Nitika Gaba

Writing - Review \& Editing: Nitika Gaba, R.Madhumathi

CONFLICT OF INTEREST STATEMENT

The authors declare that they have no competing interests.

\section{ACKNOWLEDGEMENT}

All authors contributed equally to the conception and design of the study. 
Appendix A: Checklist of Items for CSR Score

\section{APPENDICES}

\begin{tabular}{|c|l|c|}
\hline \multicolumn{1}{|c|}{ Checklist of 14 Items for CSR scores } & Average Score (Max: 5) \\
\hline S.No & \multicolumn{1}{|c|}{ Items } & 4.85 \\
\hline $\mathbf{1}$ & Education / Livelihood enhancement & 3.25 \\
\hline $\mathbf{2}$ & Skill Development & 3.35 \\
\hline $\mathbf{3}$ & Rural Development & 4.5 \\
\hline $\mathbf{4}$ & Healthcare/Sanitation/Safe Drinking water & 3.6 \\
\hline $\mathbf{5}$ & Environmental sustainability & 1.8 \\
\hline $\mathbf{6}$ & Swachh Bharat Abhiyan & 0.9 \\
\hline $\mathbf{7}$ & Prime minister relief fund/ Chief Minister Relief Fund & 0.5 \\
\hline $\mathbf{8}$ & Arm Forces Veterans & 2.3 \\
\hline $\mathbf{9}$ & Women empowerment & 2.2 \\
\hline $\mathbf{1 0}$ & Poverty, malnutrition and hunger & 1.9 \\
\hline $\mathbf{1 1}$ & Sports & 1.75 \\
\hline $\mathbf{1 2}$ & Art and Culture & 0.35 \\
\hline $\mathbf{1 3}$ & Senior citizens welfare & 0.2 \\
\hline $\mathbf{1 4}$ & Technology incubators funding & \\
\hline
\end{tabular}

Appendix B: Ranking based on Average CSR scores (14 items) for five years 2014-2015 to 201819

\begin{tabular}{|c|c|c|}
\hline Banks & Average CSR scores for five years 2014-2019 & Ranking \\
\hline Federal Bank (Pr) & 0.8143 & 1 \\
\hline South Indian Bank(Pr) & 0.6143 & 2 \\
\hline Karnataka Bank Ltd (Pr) & 0.5714 & 3 \\
\hline $\mathrm{SBI}(\mathrm{Pu})$ & 0.5143 & 4 \\
\hline ICICI Bank(Pr) & 0.5143 & 4 \\
\hline IndusInd Bank (Pr) & 0.5000 & 5 \\
\hline Kotak Mahindra Bank (Pr) & 0.4857 & 6 \\
\hline Bank of India $(\mathrm{Pu})$ & 0.4857 & 6 \\
\hline $\mathrm{PNB}(\mathrm{Pu})$ & 0.4572 & 7 \\
\hline Canara Bank $(\mathrm{Pu})$ & 0.4572 & 7 \\
\hline $\mathrm{IDBI}(\mathrm{Pu})$ & 0.4571 & 8 \\
\hline Yes Bank (Pr) & 0.4571 & 8 \\
\hline HDFC Bank(Pr) & 0.4428 & 9 \\
\hline Karur Vysya Bank (Pr) & 0.4428 & 9 \\
\hline Union Bank of India $(\mathrm{Pu})$ & 0.4000 & 10 \\
\hline Syndicate $\operatorname{Bank}(\mathrm{Pu})$ & 0.3714 & 11 \\
\hline RBL Bank Ltd(Pr) & 0.3428 & 12 \\
\hline Bank of Baroda $(\mathrm{Pu})$ & 0.2571 & 13 \\
\hline $\mathrm{UCO} \operatorname{Bank}(\mathrm{Pu})$ & 0.2429 & 14 \\
\hline Andhra Bank(Pu) & 0.2143 & 15 \\
\hline
\end{tabular}

Note: Pr (Private); Pu (Public) 


\section{REFERENCES}

Alotaibi, K., \& Hussainey, K. (2016). Quantity versus quality: the value relevance of CSR disclosure of Saudi companies. Corporate Ownership and Control, 13(2), 167-179. https://doi.org/10.22495/cocv13i2p15

Alsaid, L. (2016). Do consistent CSR activities matter for firm value? Corporate Ownership and Control, 14(1), 340-350. https://doi.org/10.22495/cocv14i1c2p6

Belasri, S., Gomes, M., \& Pijourlet, G. (2020). Corporate social responsibility and bank efficiency. Journal of Multinational Financial Management, 54(C). https://doi.org/10.1016/j.mulfin.2020.100612.

Beneish, M.D. (2001). Earning management: a perspective. Managerial Finance, 27(12), 3-17. https://doi.org/10.1108/03074350110767411

BIS. (2021). Bureau of Indian Standards. Retrieved from https://bis.gov.in

Bodhanwala, S., \& Bodhanwala, R. (2018). Does corporate sustainability impact firm profitability? Evidence from India. Management Decision, 56(8), 1734-1747. https://doi.org/10.1108/MD04-2017-0381

Bolton, B. J. (2013). Corporate social responsibility and bank performance. SSRN Electronic Journal.

Brammer, S., Millington, A., \& Rayton, B. (2007). The contribution of corporate social responsibility to organizational commitment. The International Journal of Human Resource Management, 18(10), 1701-1719. https://doi.org/10.1080/09585190701570866

Caby, J., Ziane, Y., \& Lamarque, E. (2020). The determinants of voluntary climate change disclosure commitment and quality in the banking industry. Technological Forecasting and Social Change, 161(C). https://doi.org/10.1016/j.techfore.2020.120282

Caiazza, S., Cotugno, M., Fiordelisi, F., \& Stefanelli, V. (2018). The spillover effect of enforcement actions on bank risk-taking. Journal of Banking and Finance, 91, 146-159. https://doi.org/10.1016/j.jbankfin.2018.04.008

Carbo-Valverde, S., Degryse, H., \& Rodríguez-Fernández, F. (2015). The impact of securitization on credit rationing: Empirical evidence. Journal of financial stability, 20, 36-50. https://doi.org/10.1016/j.jfs.2015.06.004

Cheng, B., Ioannou, I., \& Serafeim, G. (2013). Corporate social responsibility and access to finance. Strategic Management Journal, 35(1), 1-23. https://doi.org/10.1002/smj.2131

Chih, H. L., Shen, C. H., \& Kang, F. C. (2008). Corporate social responsibility, investor protection, and earnings management: Some international evidence. Journal of Business Ethics, 79, 179-198. https://doi.org/10.1007/s10551-007-9383-7

Dechow, Patricia M., \& Ge, W. (2003). Earnings, cash flows, persistence and growth. Working Papers. University of Michigan.

Deniz, M. \& Suarez, M. (2005). Corporate social responsibility and family business in Spain, Journal of Business Ethics, 56(1), 27-41. https://doi.org/10.1007/S10551-004-3237-3 
Dhaliwal, D. S., Radhakrishnan, S., Tsang, A., \& Yang, Y. G. (2011). Non-financial disclosure and analyst forecast accuracy: International evidence on corporate social responsibility disclosure. The Accounting review, 87(3), 723-759. https://doi.org/10.2308/accr-10218

Ding, D. K., Ferreira, C., \& Wongchoti, U. (2016). Does it pay to be different? Relative CSR and its impact on firm value. International Review of Financial Analysis, 47, 86-98. https://doi.org/10.1016/j.irfa.2016.06.013

Fatemi, A., Fooladi, I; \& Tehranian, H. (2015), Valuation effects of corporate social responsibility, Journal of Banking \& Finance, 59, 182-192. https://doi.org/10.1016/j.jbankfin.2015.04.028

Ferrell, A., Liang, H., \& Renneboog, L. (2016). Socially responsible firms. Journal of Financial Economics, 122(3), 585-606. https://doi.org/10.1016/j.jfineco.2015.12.003

Freeman, R.E. (1984). Strategic management: A stakeholder approach. Cambridge University Press.

Giuli, A.D, \& Kostovetsky, L. (2014). Are red or blue companies more likely to go green? Politics and corporate social responsibility. Journal of Financial Economics, 111(1), 158-180. https://doi.org/10.1016/j.jfineco.2013.10.002

Garcia-Castro, R., Ariño, M. A., \& Canela, M. A. (2010). Does social performance really lead to financial performance? Accounting for Endogeneity. Journal of Business Ethics, 92(1), https://doi.org/107-126. 10.1007/s10551-009-0143-8

García-Sánchez, I., \& García-Meca, E. (2017). CSR engagement and earnings quality in banks. The moderating role of institutional factors. Corporate Social Responsibility and Environmental Management, 24(2), 45-158. https://doi.org/10.1002/csr.1405

Godfrey, P. (2005). The relationship between corporate philanthropy and shareholder wealth: A risk management perspective. Academy of Management Review, 30(4), 777-798. https://doi.org/10.2307/20159168

Greening, D; \& Turban, D. (2000). Corporate social performance as a competitive advantage in attracting a quality workforce. Business \& Society, 39(3), 254-280. https://doi.org/0.1177/000765030003900302

Grougiou, V., Leventis, S., Dedoulis, E; \& Owusu-Ansah, S. (2014). Corporate social responsibility and earnings management in U.S. banks. Accounting Forum, 38(3), 155-169. https://doi.org/10.1016/j.accfor.2014.05.003

Hafez, H. M. (2015). Corporate social responsibility and financial performance: An empirical study on Egyptian banks. Corporate Ownership and Control, 12(2), 107-127. https://doi.org/10.22495/cocv12i2p9

Haniffa, R., \& Cooke, T. (2002). Culture, Corporate Governance and disclosure in Malaysian Corporations, Abacus, 38(3), 317-329. https://doi.org/10.1111/1467-6281.00112

He, F., Miao, X., Wong, C.W.Y., \& Tang, Y. (2020). Corporate Social Responsibility and Operating Performance: The role of local character in emerging economies. Sustainability, 12(12), 4874. https://doi.org/10.3390/su12124874. 
Hong, Y., \& Andersen, M. (2011). The relationship between corporate social responsibility and earnings management: An exploratory study. Journal of Business Ethics, 104(4), 461-471. https://doi.org/10.1007/s10551-011-0921-y

Iannotta, G., Nocera, G., \& Sironi, A. (2013). The impact of government ownership on bank risk. Journal of Financial Intermediation, 22(2), 152-176. https://doi.org/10.1016/j.jfi.2012.11.002

Jiao, Y. (2010). Stakeholder welfare and firm value. Journal of Banking \& Finance, 34(10), 2549-2561.

Kanagaretnam, K., Lim, C., \& Lobo, G. (2014). Effects of international institutional factors on earnings quality of banks. Journal of Banking \& Finance, 39, 87-106. https://doi.org/10.1016/j.jbankfin.2013.11.005

Kayode, O. F., Obamuyi, T. M., Owoputi, J. A., \& Adeyefa, F. A. (2015). Credit risk and bank performance in Nigeria. IOSR Journal of Economics and Finance, 6(2), 21-28.

Khanna, N., \& Sonti, R. (2004). Value creating stock manipulation: feedback effect of stock prices on firm value. Journal of Financial Markets, 7(3), 237-270. https://doi.org/10.12691/jfe-4-5-5

Kim, Y., Park, M., \& Wier, B. (2012). Is earnings quality associated with Corporate Social Responsibility? The Accounting Review, 87(3), 761-796. https://doi.org/0.3390/su11154116

Kothari, S., Leone, A., \& Wasley, C. (2005), Performance matched discretionary accrual measures, $\begin{array}{llll}\text { Journal of Accounting and } & \text { 163-197. }\end{array}$ https://doi.org/10.1016/j.jacceco.2004.11.002

Krippendorff, K. (1980). Content analysis: An introduction to its methodology. (1st ed.). SAGE Publications, pp.21.

Kroeger, A., \& Weber, C. (2014). Developing a conceptual framework for comparing social value creation. Academy of Management Review, 39(4), 513-540. https://doi.org/10.5465/amr.2012.0344

Levine, R. (2005). Finance and growth: Theory and evidence. Handbook of economic growth, 1(A), 865-934. https://doi.org/10.1016/S1574-0684(05)01012-9

Lin, C., Yang, H., \& Liou, D. (2009). The impact of corporate social responsibility on financial performance: Evidence from business in Taiwan. Technology in Society, 31(1), 56-63. https://doi.org/10.1016/j.techsoc.2008.10.004

Lotto, J. (2019). Evaluation of factors influencing bank operating efficiency in Tanzanian banking sector. Cogent Economics \& $\quad$ Finance, $7(1), \quad 166-192$. https://doi.org/10.1080/23322039.2019.1664192

Luo, X., \& Bhattacharya, C. (2009). The debate over doing good: Corporate social performance and $\begin{array}{llll}\text { firm-idiosyncratic } \quad \text { Risk, Journal of marketing, } & \text { 73, }\end{array}$ https://doi.org/10.1509/jmkg.73.6.198

Lys, T., Naughton, J. P., \& Wang, C. (2015). Signalling through corporate accountability reporting. $\begin{array}{llll}\text { Journal of Accounting and } & \text { 56-72. }\end{array}$ https://doi.org/10.1016/j.jacceco.2015.03.001 
MCA. (2021). Ministry of corporate affairs, Acts and rule. Retrieved from https://www.mca.gov.in/content/mca/global/en/acts-rules/ebooks.html

McGuire, J., Sundgren, A., \& Schneeweis, T. (1988). Corporate social responsibility and firm financial performance. Academy of Management Journal, 31(4), 854-972. https://doi.org/10.5465/256342.

Merton, R. C. (1987). A simple model of capital market equilibrium with incomplete information. The Journal of Finance, 42(3), 483-510. https://doi.org/10.1111/j.1540-6261.1987.tb04565.x

Mishra, S., \& Suar, D. (2010). Does corporate social responsibility influence firm performance of Indian companies? Journal of Business Ethics, 95(4), 571-601. https://doi.org/10.1007/s10551010-0441-1

Mitra, N., Akhtar, A., \& Gupta, A. (2018). Communicating corporate social responsibility in the post mandate period: Evidence from India. International Journal of Corporate Social Responsibility, 3(1). https://doi.org/10.1186/s40991-018-0033-4

Mittal, R., Sinha, N., \& Singh, A. (2008). An analysis of linkage between economic value added and corporate social responsibility. Management Decision, 46(9), 1437-1443. https://doi.org/10.1108/00251740810912037

Mohd Ghazali, N. (2007). Ownership structure and corporate social responsibility disclosure: some Malaysian evidence. Corporate Governance: The International Journal of Business in Society, 7(3), 251-266. https://doi.org/10.1108/14720700710756535

Nandy, M., \& Lodh, S. (2012). Do banks value the eco-friendliness of firms in their corporate lending decision? Some empirical evidence. International Review of Financial Analysis, 25, 83-93. https://doi.org/10.1016/j.irfa.2012.06.008

Nekhili, M., Nagati, H., Chtioui, T., \& Rebolledo, C. (2017). Corporate social responsibility disclosure and market value: Family versus non-family firms. Journal of Business Research, 77, 41-52. https://doi.org/10.1016/j.jbusres.2017.04.001

Nguyen, T., Duong, H. N., \& Singh, H. (2016). Stock market liquidity and firm value: An empirical examination of the Australian market. International Review of Finance, 16(4), 639-646. https://doi.org/10.1111/irfi.12082

Orlitzky, M., \& Benjamin, J.D. (2001). Corporate social performance and firm risk: A meta-analytic review. Business and Society, 40(4), 369-396. https://doi.org/10.1177/000765030104000402

Oxibar, B. (2005). La diffusion d'information sociétale: outils de mesure et déterminants: une comparaison multi supports. Working Papers, Paris Dauphine University.

Palazzo, M., Vollero, A., \& Siano, A. (2020). From strategic corporate social responsibility to value creation: an analysis of corporate website communication in the banking sector. International Journal of Bank Marketing, 38(7), 1529-1552. https://doi.org/10.1108/IJBM-04-2020-0168

Paul, C. J., \& Siegel, D. S. (2006). Corporate social responsibility and economic performance. Journal of Productivity Analysis, 26(3), 207-211. https://doi.org/10.1007/s11123-006-0016-4 
Prior, D., Surroca, J., \& Tribó, J. (2008). Are socially responsible managers really ethical? Exploring the relationship between earnings management and corporate social responsibility. Corporate Governance: An International Review, 16(3), 160-177. https://doi.org/10.1111/j.14678683.2008.00678.x

Rashid, A., \& Lodh, S.C. (2008). The influence of ownership structures and board practices on corporate social disclosures in Bangladesh. Research in Accounting in Emerging Economies, 8, 211-237. http://dx.doi.org/10.1016/S1479-3563(08)08008-0

Scholtens, B. (2008). Corporate social responsibility in the international banking industry. Journal of Business Ethics, 86(2), 159-175. https://doi.org/10.1007/s10551-008-9841-x

Servaes, H., \& Tamayo, A. (2013). The impact of corporate social responsibility on firm value: The role of customer awareness. Management Science, 59(5), 1045-1061. http://dx.doi.org/10.1287/mnsc. 1120.1630

Sharfman, M.P., \& Fernando, C.S. (2008). Environmental risk management and the cost of capital, Strategic Management Journal, 29(6), 569-592. https://doi.org/10.1002/smj.678

Thome, F. (2020). Corporate responsibility in the age of irresponsibility: A symbiotic relationship between CSR and the financial crisis. IISD Commentary. Retrieved from https://www.iisd.org/pdf/2009/csr_financial_crisis.pdf.

Thompson, P., \& Cowton, C. (2004). Bringing the environment into bank lending: implications for environmental reporting. The British Accounting Review, 36(2), 197-218. https://doi.org/10.1016/j.bar.2003.11.005

Van Beurden, P., \& Gössling, T. (2008). The worth of values - A literature review on the relation between corporate social and financial performance. Journal of business ethics, 82(2), 407-424. https://doi.org/10.1007/s10551-008-9894-x

Waddock, S. A., \& Graves, S. B. (1997). The corporate social performance-financial performance link. Strategic Management Journal, 18(4), 303-319. https://doi.org/10.1002/(SICI)10970266(199704)18:4<303::AID-SMJ869>3.0.CO;2-G

Wood, A., \& Mc Conney, S. (2018). The impact of risk factors on the financial performance of the commercial banking sector in Barbados. Journal of Governance and Regulation, 7(1), 76-93.

Zeng, T. (2016). Corporate social responsibility, tax aggressiveness, and firm market value. Accounting Perspectives, 15(1), 7-30. https://doi.org/10.1111/1911-3838.12090

\section{Copyrights}

Copyright for this article is retained by the author(s), with first publication rights granted to the journal. This is an open-access article distributed under the terms and conditions of the Creative Commons Attribution license (https://creativecommons.org/licenses/by/4.0). 